\title{
Bazı Tarihi Yerleşimlere Ait Çevresel Faktörlerin CBS Destekli Analizi; Kilikya Bölgesi Örneği
}

\author{
İlker KAYA ${ }^{1}$, Ayşegül DEMİR YETİ̧⿻²* \\ ${ }^{1}$ Bitlis Eren Üniversitesi, Fen Bilimleri Enstitüsü, Arkeometri, Bitlis \\ ${ }^{2}$ Bitlis Eren Üniversitesi, Mühendislik-Mimarlı Fakültesi, Çevre Mühendisliği Bölümü, Bitlis \\ (ORCID: 0000-0001-5383-5245) (ORCID: 0000-0003-4745-2445)
}

\begin{abstract}
Öz
Alanya ile İskenderun Körfezi arasında kalan bölge eski çağlardaki ismiyle Kilikya Bölgesi olarak bilinmektedir. Kilikya Bölgesi coğrafi ve jeolojik yapılarından dolayı Limonlu Çayı sınır kabul edilerek Dağlık Kilikya ve Ovalık Kilikya olarak ikiye ayrılmaktadır. Eski çağlarda Kilikya Bölgesi’nde çok sayıda şehir oluşturulduğu bilinmektedir. Bu çalışmada, bu yerleşimlerden bazı örnekler incelenip Coğrafi Bilgi Sistemi (CBS) yardımıyla bölgeye ait yükselti, bakı, eğim, sıcaklık, yağış, toprak türleri, kayaç yapısı, su kaynakları, karayolları gibi çevresel faktörler kullanılarak haritalar elde edilmiştir. Ayrıca Kilikya Bölgesi için dikkate alınan bu çevresel faktörlerin tarihi yerleşimler kurulurken yer seçimine etkisi incelenerek analizleri yapılmıştır. Yapılan analizlere göre, çoğunlukla güney ve güneydoğu yönleri bakı yönü olarak seçilmiştir. Yükseklik bakımından yerleşim yeri olarak daha çok düz alanlar tercih edilmişken, eğimin \%10'dan fazla olduğu kesimler ise yerleşim yeri olarak tercih edilmemiştir. Tüm yerleşimler verimli topraklar üzerine kurulmuştur. Su kaynakları açısından daha çok, büyük akarsulara yakın yerler ve deniz seviyesine yakın sahiller yerleşim yeri seçiminde tercih sebebi olmuştur. Çalışma, taşınmaz kültür varlıklarımızın en önemli figürlerinden olan bu tarihi yerleşimlerin sonraki nesillere korunarak aktarılabilmesi ve henüz keşfedilmemiş yerleşimlerin tespiti aşamasında özellikle CBS'nden faydalanılması adına büyük önem arzetmektedir.
\end{abstract}

Anahtar kelimeler: Kilikya, tarihi yerleşimler, çevresel faktörler, CBS.

\section{Analysis Using GIS of Environmental Factors of Some Historical Settlements; Cilicia Region}

\begin{abstract}
The area between Alanya and İskenderun Bay is known as Cilicia region in ancient times. Due to its geographical and geological structures, the Cilicia region is divided into two as Mountainous Cilicia and Ovalic Cilicia considered as a border with Limonlu stream. It is known that many cities were created in Cilicia region in ancient times. In this study; some examples of these settlements were examined and maps of environmental factors such as elevation, look, slope, temperature, precipitation, soil types, rock structure, water resources, roads were produced by using Geographical Information System (GIS). In addition, the impact of these environmental factors on the choice of location during the establishment of historical settlements was examined for Cilicia. In addition, the impact of these environmental factors on the choice of location during the establishment of historical settlements was examined for Cilicia. According to the analysis, mostly south and southeast directions were chosen as the aspect. In terms of height, more flat areas were preferred, while slopes of more than $10 \%$ were not preferred as settlements. All settlements are built on fertile soil. In terms of water resources, mostly the places close to the big rivers and the coasts near the sea level have been preferred for settlement selection. The study is important in terms of preserving and transferring these historical settlements which are one of the most important figures of our immovable cultural assets to the next generations. It is also of great importance especially using of GIS for the identification of settlements that have not yet been discovered.
\end{abstract}

Keywords: Cilicia, environmental factors, historical settlements, GIS.

*Sorumlu yazar: $\frac{\text { ademir@ beu.edu.tr }}{\text { Geliş Tarihi: 04.11.2019, Kabul Tarihi: 08.04.2020 }}$ 


\section{Giriş}

Kültür tarihimiz açısından arkeolojik vasfa sahip yerleşim yerleri ait oldukları dönemin toplumlarının sosyal ve kültürel yapıları ve yaşam biçimleri hakkında önemli bilgiler vermektedir. İnsanların toplu halde yaşamaya başlamasında etkili olan sebeplerin başında daha güvenli yaşama isteği gelmektedir. Üretim ilişkilerinin şekillendirdiği toplumlar güvenlik içinde olmak için değişik stratejiler kullanmışlardır. Birey olarak insan, doğmadan önce güvenli bir ortamda gelişimini tamamlar ve dünyaya geldikten sonra da güvende olma isteğini sürdürür. Maslow’un “Gereksinimler Kuramı'na göre güvende olma ihtiyacı temel ihtiyaçlardan sonra ikinci sırada yer almaktadır. Bundan dolayı, yerleşik hayata geçildikten sonra güvenli şehirler oluşmaya başlamıştır [1].

İlk çağlardan beri birçok medeniyete sahne olmuş Kilikya, arkeolojik açıdan oldukça zengindir. Bölge, neredeyse her kısmında karşımıza çıkan ve Roma Dönemi izlerini taşıyan yerleşim yerleriyle dev bir açık hava müzesini andırmaktadır [2]. Arkeologlar ve Sanat Tarihçilerinin karşılaştıkları en önemli problemlerden biri, nereye bakacakları ve kazıya nereden başlayacaklarıdır. Yüzey araştırmaları ve kazılar hem zaman açısından hem de ekonomik açıdan külfet oluşturmaktadır. Birçok alanda olduğu gibi arkeolojik çalışmalarda da Coğrafi Bilgi Sistemi (CBS) kullanımı ve arkeolojik verilere ait analizlerin önemi giderek artmaktadır. Bununla birlikte, CBS kullanımı bir bölgede arkeolojik araştırmalar için, yüzey araştırmaları ve sahadan toplanan alansal verilerin analizini planlamada zaman ve harcama açısından tasarruf sağlamaktadır [3]. CBS yöntemleri ile arkeolojik çalışmalarda, çalışma alanlarına ait veriler arttıkça yapılabilecek uygulamalar da çeşitlenmektedir. Arkeolojik kazılarla elde edilen verilerin haritalarla birleştirilmesi, yeni haritaların oluşturulması ve kıyaslanması söz konusu olduğunda CBS kullanımı gerekmektedir. Bu bilgisayar destekli sistem; değişik verilerin, haritalar üzerinde alanlara, çizgilere ve noktalara bağlanmasını sağlar. CBS'nin gelişmesi ve daha çok kullanılmaya başlanması yeni çalışmaların ve araştırmaların önünü açmaktadır [4, 5]. CBS yazılımları desteğiyle yapılan analizler sonucunda bölgedeki eski yerleşimler için yer seçimlerinde etkili olan çevresel faktörler anlaşılmaya çalışılmıştır. Bu kapsamda Kardeş (2010) ve Pişkin (2011) tarafindan yapılan çalışmalarda CBS'nin kullanıldığı ve yükseklik, eğim, bakı gibi çevresel faktörlerle ilgili analizlerin yapıldığ 1 görülmektedir [6,7].

Bu çalışmada; Kilikya Bölgesi'nde bulunan tarihi yerleşim yerleri baz alınarak yükselti, bakı, eğim, sıcaklık, yağış, toprak türleri, kayaç yapısı, su kaynakları ve karayolları gibi çevresel faktörlere ait bilgiler CBS'ne aktarılmış ve oluşturulan haritaların analizleri yapılarak bu parametrelerden hangilerinin o dönemin toplumsal yapısı, yaşayış şekilleri ve yaşam alanlarının seçimi üzerinde etkili olduğu tartışılmıştır. Bölgeye ait yapılmış çok sayıda arkeolojik çalışma mevcut olmasına rağmen CBS kullanılarak Roma Dönemi’ne ait yerleşimlerin yer seçimi ile ilgili tahminine yönelik yapılmış çalışma olmaması bu çalışmayı özgün kılan en büyük özelliktir.

\section{Materyal ve Metot}

\subsection{Kilikya Bölgesi}

Kilikya olarak adlandırılan bölge, Akdeniz Bölgesi üzerinde yer almaktadır ve bölgenin kuzey sınırlarını Toros Dağları'nın çizmiş olduğu doğal hat belirlemektedir. Herodotos, Ptolemaios ve Strabon gibi coğrafyacılar Kilikya Bölgesi'ni; Dağlık Kilikya ve Ovalık Kilikya olarak ikiye ayırmışlardır [8]. Strabon Dağlık Kilikya'yı tanımlarken "kıyıları dar ve düzlükler çok az sayıdadır" demiştir [9]. Dağlık Kilikya' da bulunan yerleşimlerin daha küçük ölçekli olmasının nedeni dağlık alanların çok olmasıdır. Ovalık Kilikya'da ise dağların ovadan uzak olması nedeniyle daha büyük şehirler kurulmuştur [8]. Alanya'dan Limonlu Çayı'na kadar uzanan Dağlık Kilikya jeolojik olarak daha değişik görünüştedir. Kuzeyde Toroslar, güneyde Akdeniz ve doğuda Amanos Dağları Kilikya Bölgesi'ni diğer bölgelerden ayırıp, doğal korunaklı bir yer haline getirir. Bu nedenle Kilikya'da yüzlerce yerleşim yeri kurulmuş ve en ücra yerlerinde bile yerleşimlerin olduğu düşünülmektedir [10].

Günümüzde Kilikya Bölgesi olarak bilinen ve çalışma alanı olarak seçilen bölgeye ait lokasyon sınırı Şekil 1'de görülmektedir. Bu alanın seçilmesindeki en önemli neden bölgenin Roma Dönemi için adeta bir açık hava müzesi görünümünde olmasıdır. Çalışma alanı sınırı içerisindeki Olba/Uzuncaburç, Koriykos, Elaiussa Sebaste, Soli Pompeipolis, Tarsos, Anavarza, Kastabala, Anemirium, Nagidos ve Kelenderis isimli 10 adet tarihi yerleşim yerine ait detaylı koordinat bilgisi ve genel bilgiler Tablo 1'de 
sunulmuştur. Ayrıca bölgede yapılan arazi çalışmaları sırasında alınan görüntüler Şekil 2'de yer almaktadır.

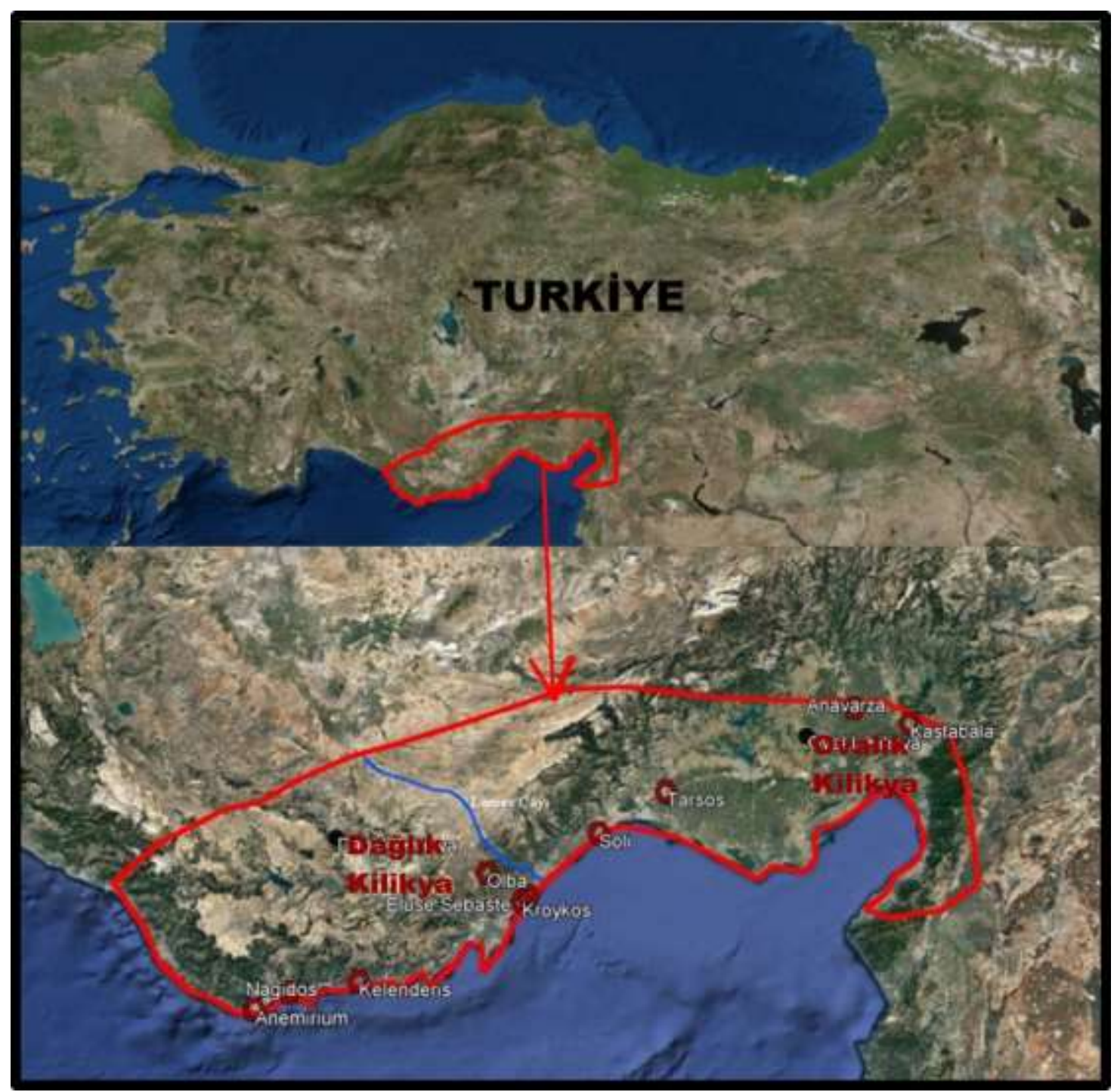

Şekil 1. Kilikya bölgesi lokasyon haritası [11]

Tablo 1. Yerleşim yerlerine ait koordinat bilgisi ve genel bilgiler

\begin{tabular}{lcccccc}
\hline \multirow{2}{*}{ Tarihi Yerleşim } & \multirow{2}{*}{ Bölge } & \multirow{2}{*}{ il } & \multirow{2}{*}{ İlçe } & \multirow{2}{*}{ Alan (ha) } & \multicolumn{2}{c}{ Koordinatlar } \\
\cline { 5 - 7 } & & & & & & \\
\hline Uzuncaburç/Olba & Dağlık Kilikya & Mersin & Silifke & 17.50 & 586314 & 4049226 \\
Koriykos & Dağlık Kilikya & Mersin & Edremit & 62 & 602487 & 4035335 \\
Elaiussa Sebaste & Dağlık Kilikya & Mersin & Edremit & 40 & 605198 & 4037997 \\
Soli Pompeipolis & Ovalık Kilikya & Mersin & Merkez & 17 & 637413 & 4067479 \\
Tarsos & Ovalık Kilikya & Mersin & Tarsus & 3 & 668545 & 4086860 \\
Anavarza & Ovalık Kilikya & Adana & Kozan & 13 & 756941 & 4126666 \\
Kastabala & Ovalık Kilikya & Osmaniye & Merkez & 9.5 & 250301 & 4118175 \\
Anemirium & Dağlık Kilikya & Mersin & Anamur & 63 & 482235 & 3986460 \\
Nagidos & Dağlı Kilikya & Mersin & Bozyazı & 14 & 498097 & 3994881 \\
Kelenderis & Dağlık Kilikya & Mersin & Aydıncık & 12 & 529030 & 3999980 \\
\hline
\end{tabular}




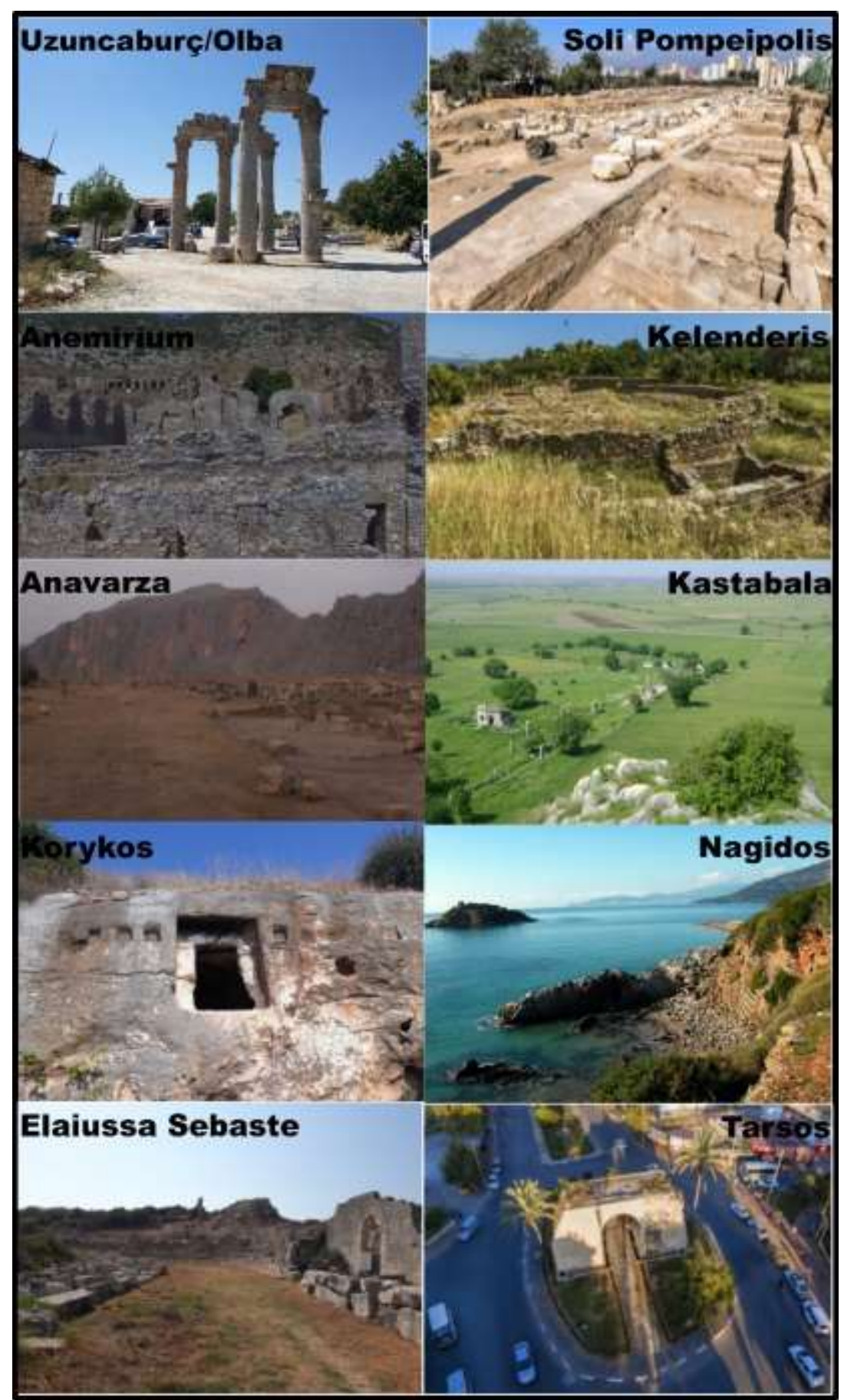

Șekil 2. Kilikya Bölgesi’ndeki yerleșimlere ait arazi gözlemleri sırasında alınan görüntüler (Fotoğraf: İlker KAYA, 16.08.2017)

\subsection{Metodoloji}

Bu çalışmada, öncelikli olarak eski yerleşimlerle ilgili çevresel faktörlere ait veriler gözden geçirilerek, CBS'nin arkeolojik çalışmalarda daha önceki kullanımları incelenmiş ve çalışma kapsamında kullanılabilecek yöntemler belirlenmiştir. Çalışma alanı ve alandaki tarihi eserlerin kuruldukları yerlerin seçilme nedenlerinin çevresel faktörler özelinde daha iyi anlaşılabilmesi için bir ön arazi çalışması gerçekleştirilmiş ve alanının tamamı görsel olarak analiz edilerek, yerleşim yerlerinin koordinat bilgisi alınmıştır. Çalışma sahasındaki yerleşim yerlerine ait alınan koordinatların coğrafik doğrulaması, lokasyon, yükselti, bakı, eğim, sıcaklık, yağış, toprak türleri, kayaç yapısı, su kaynakları ve karayolları gibi çevresel faktörlerin haritaları için CBS ArcGIS ArcMap 10.5 programından faydalanılmıştır. Amerika Birleşik Devletleri Jeoloji Servisi (USGS)'nden bölgenin sayısal yükseklik modelleri için altlık 
DEM 30 m aralıklı (Digital Elevation Model) verisi temin edilmiş [12] ve bu modellerden eğim ve bakı haritaları oluşturulmuştur. MTA Jeoloji Portalı'ndan jeoloji haritaları üretilmiştir [13]. Günümüzdeki karayolları ve Roma Dönemi karayollarına ait karayolu haritaları elde edilmiş ve bu sayede karayolu ağları birbirleriyle karşılaştırılmıştır [14].

\section{Bulgular ve Tartışma}

Çalışma alanı olarak belirlenen Kilikya Bölgesi'ndeki bazı eski yerleşim yerlerinin seçiminde önemli olan yükselti, bakı, eğim, sıcaklık, yağış, toprak türleri, kayaç yapısı, su kaynakları ve karayolları gibi çevresel faktörlere ait CBS destekli yapılan analizler değerlendirilerek sunulmuştur.

\subsection{Yükselti}

Çevresel faktörlerden ilki yükselti parametresidir. Kilikya Bölgesi’nde çalışma alanı olarak belirlenen tarihi yerleşimlerin $1 \mathrm{~m}-1150 \mathrm{~m}$ arasında bir yükseltiye sahip olduğu görülmektedir. Bölgedeki yerleşim yerlerine ait hazırlanan yükselti haritası (USGS-30 m aralıklı DEM) Şekil 3'de görülmektedir [12]. Çalışma alanındaki her bir yerleşim yerinin sınırı içerisinde en az yükselti değeri ile en fazla yükselti değeri baz alınarak oluşturulan ortalama değerler Tablo 2'de verilmiştir. Bölgenin tamamı dikkate alındığı zaman; Dağlık Kilikya için tercih edilen yerleşimlerin büyük çoğunluğu özelikle sahil kesimleri ve rakımı düşük yerler iken, Ovalık Kilikya için kıyıya yakın ve korunaklı olabilecek yerler tercih edilmiştir.

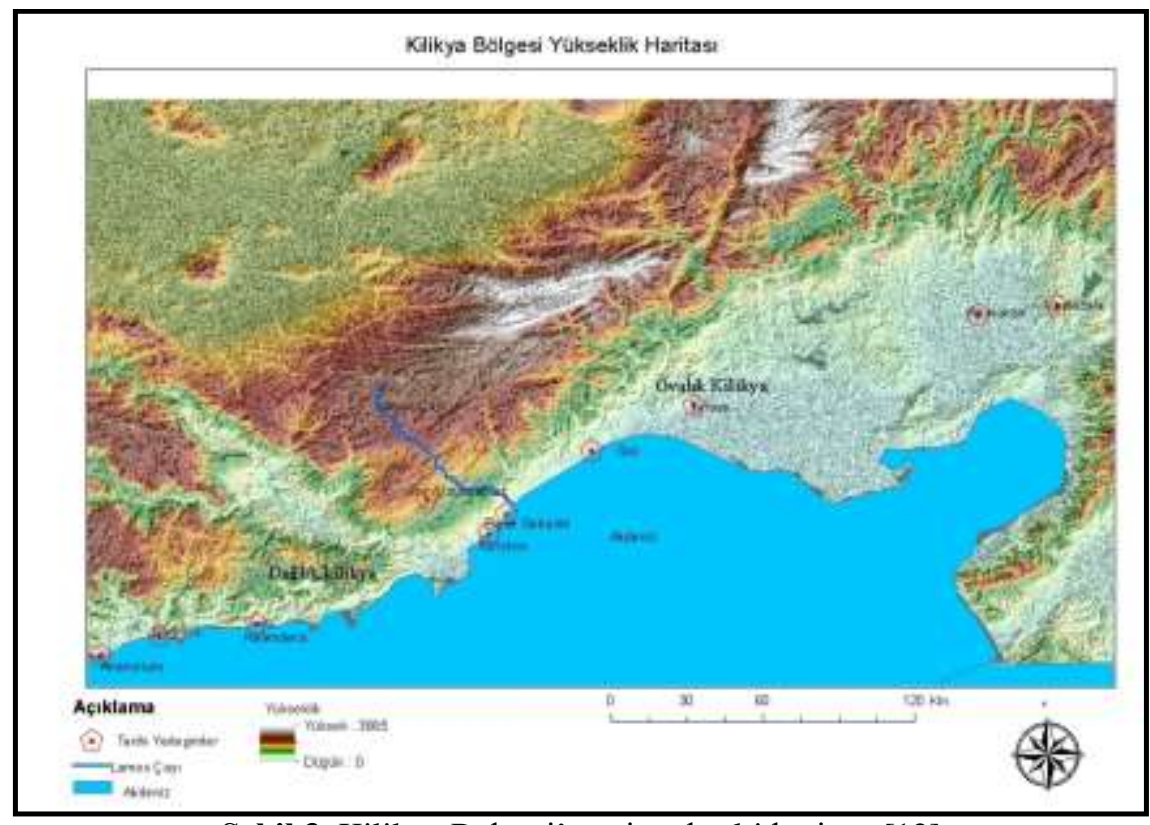

Şekil 3. Kilikya Bölgesi'ne ait yükselti haritası [12]

Tablo 2. Çalışma alanının ortalama yükselti değerleri

\begin{tabular}{lc}
\hline Tarihi Yerleşim Yeri & Ortalama Yükselti Değerleri (m) \\
\hline Anemurium & 39 \\
Olba/Uzuncaburc & 1150 \\
Nagidos & 19 \\
Kelenderis & 11.5 \\
Korycus & 5.5 \\
Elaiussa Sebaste & 19 \\
Soli Pompeipolis & 9.5 \\
Tarsos & 23 \\
Anavarza & 63 \\
Kastabala & 118.5 \\
\hline
\end{tabular}




\subsection{Bakı}

Çevresel faktörlerden ikincisi bakı parametresidir. Kilikya Bölgesi’nde çalışma alanı olarak belirlenen tarihi yerleşim yerlerine ait bakı haritası USGS-30 m aralıklı DEM kullanılarak hazırlanmıştır [12]. Bakı yönleri haritası analiz edildiğinde yerleşimlerin yönleri farklılıklar göstermekle birlikte en çok tercih edilen kuzeybatı ve güneydoğu yönleri olmuştur. Bununla birlikte, bakı açısından kuzey yönü hiç tercih edilmemiştir. Çalışma alanındaki her bir yerleşim yerine ait oluşturulan bakı yönleri Tablo 3'de yer almaktadır. Kilikya Bölgesi'ndeki yerleşim yerlerine ait hazırlanan bakı haritası Şekil 4'de görülmektedir.

Tablo 3. Çalışma alanının bakı yönleri

\begin{tabular}{lc}
\hline Tarihi yerleşim yeri & Bakı yönleri \\
\hline Anemurium & Kuzey doğu \\
Olba/Uzuncaburc & Güneydoğu \\
Nagidos & Güney \\
Celenderis & Güneydoğu \\
Korycus & Güney \\
Elaiussa Sebaste & Kuzey batı \\
Soli Pompeipolis & Kuzeybatı \\
Tarsos & Kuzeybatı \\
Anavarza & Güneydoğu \\
Kastabala & Güney batı \\
\hline
\end{tabular}

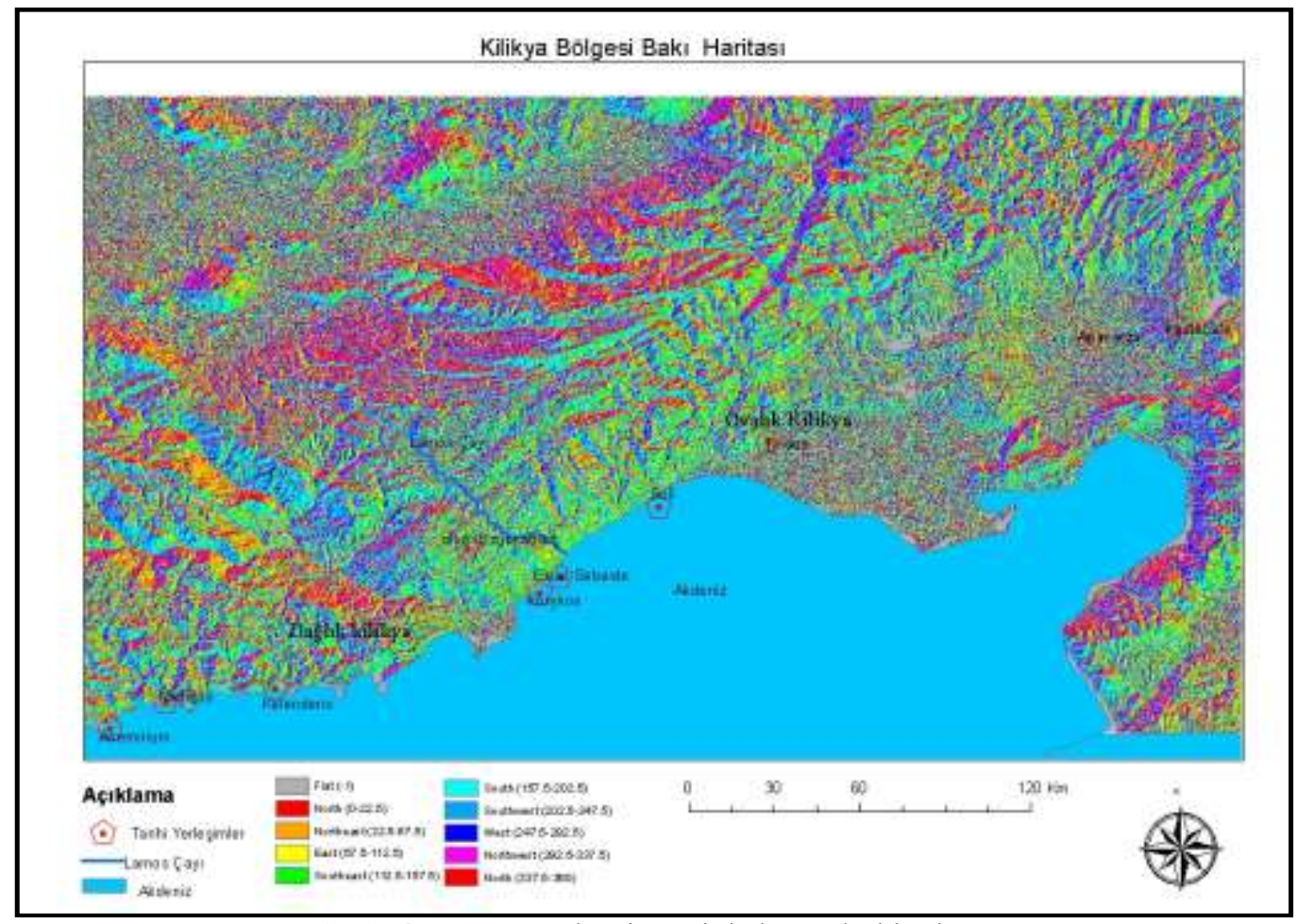

Şekil 4. Kilikya Bölgesi’ne ait bakı yönleri haritası

\section{3. Ĕ̆im}

Çevresel faktörlerden üçüncüsü eğim parametresidir. Çalışma alanındaki yerleşimler için eğim değerleri dikkate alınarak yapılan analizde Kilikya Bölgesi'ndeki bazı tarihi yerleşimlerin tamamı \%10 eğimin altındaki bölgelerde bulunmaktadır. Bununla birlikte, genellikle düz alanlar yerleşim yeri olarak seçilmiştir. Kilikya Bölgesi'ndeki yerleşim yerlerine ait hazırlanan eğim haritası Şekil 5'de yer almaktadır. 


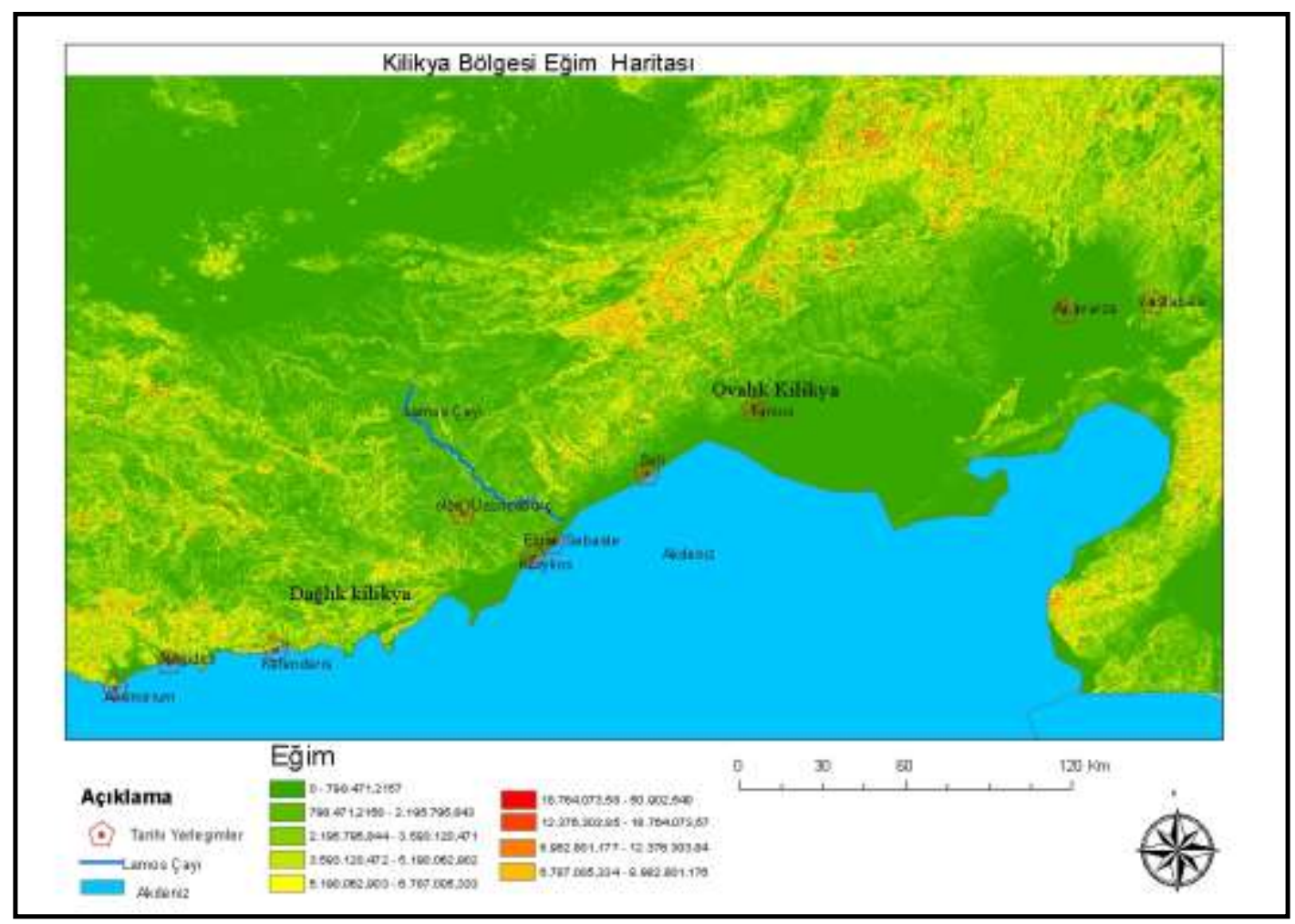

Şekil 5. Kilikya Bölgesi’ne ait eğim haritası

\subsection{Sicaklık}

Çevresel faktörlerden dördüncüsü sıcaklık parametresidir. Meteoroloji Genel Müdürlüğü'nün ulaşılabilen 1927-2017 yılları arasındaki sıcaklık değerlerine [15] bakıldığı zaman çalışma alanına ait en düşük ortalama sıcaklık değeri $14{ }^{\circ} \mathrm{C}$ ile Kastabala' da ve en yüksek ortalama sıcaklık değeri ise 19.5 ${ }^{\circ} \mathrm{C}$ ile Nagidos yerleşimindedir. Tablo 4' de ve Şekil 6' da yer alan ortalama sıcaklık değerlerine bakıldığ 1 zaman genelde birbirine çok yakın değerlerde olmakla birlikte $18.5^{\circ} \mathrm{C}$ üzerinde olduğu sıcaklıktaki yerlerin, yerleşim yeri olarak tercih edildiği görülmektedir.

Tablo 4. 1927-2017 yılları arasındaki ortalama sıcaklık değerleri [15]

\begin{tabular}{lc}
\hline Tarihi Yerleşim Yeri & Ortalama Sıcaklık Değerleri $\left({ }^{\circ} \mathbf{C}\right)$ \\
\hline Anemurium & 19.3 \\
Olba/Uzuncaburc & 15.2 \\
Nagıdos & 19.5 \\
Celenderis & 19.1 \\
Corycus & 18.5 \\
Elaıussa Sebaste & 18.5 \\
Solı Pompeipolis & 19.0 \\
Tarsos & 19.1 \\
Anavarza & 19.2 \\
Kastabala & 14.0 \\
\hline
\end{tabular}




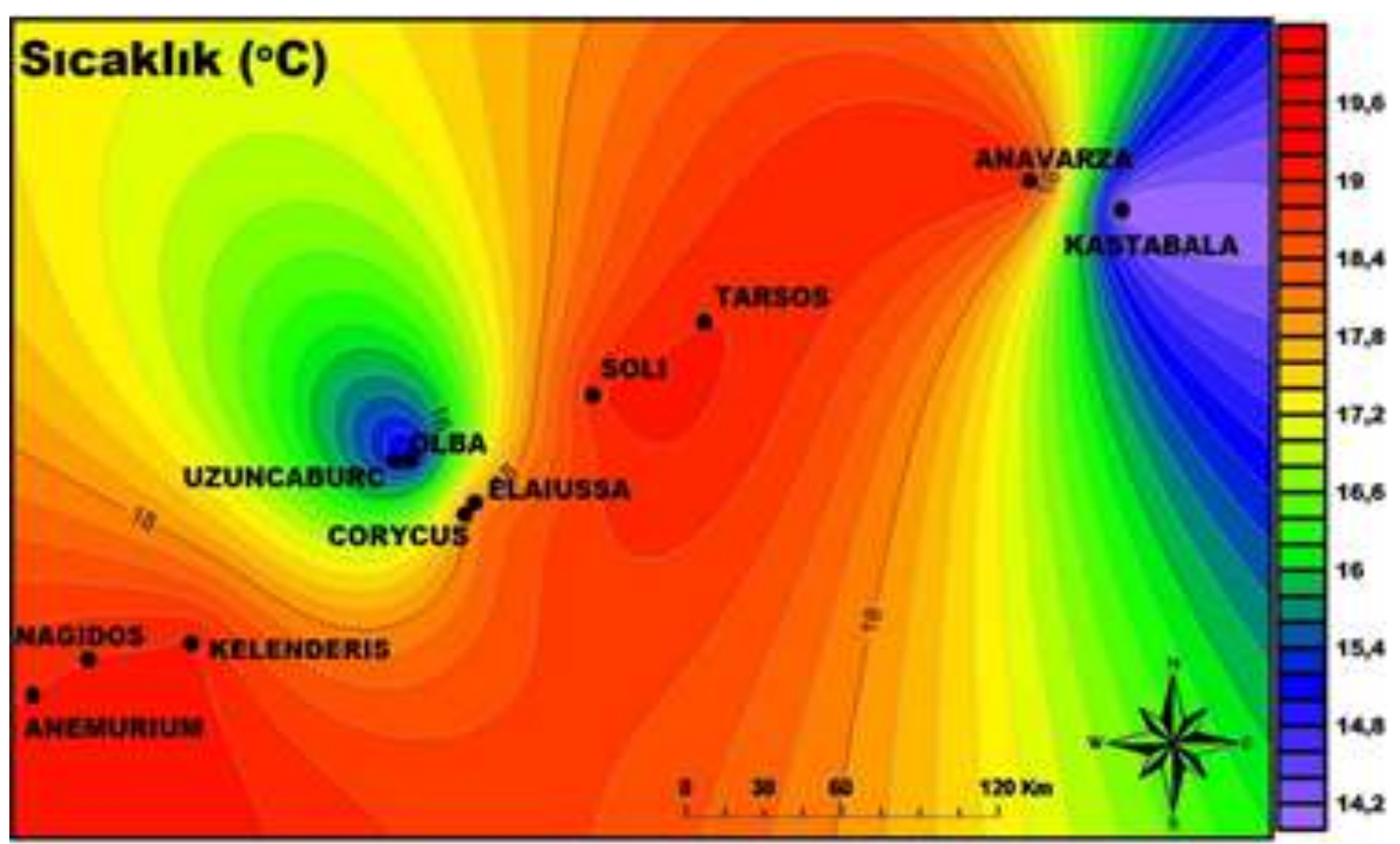

Şekil 6. Çalışma alanının 1927-2017 yılları arasındaki ortalama sıcaklık değerlerinin alansal dağılımı [15]

\subsection{Yağış}

Çevresel faktörlerden beşincisi yağış parametresidir. Meteoroloji Genel Müdürlüğü'nün ulaş1labilen 1927-2017 yılları arasındaki çalışma alanına ait en yüksek ortalama yağış değeri [15] 1049 mm değeri ile Anemurium tarihi yerleşiminde, en düşük yağış değeri ise $617 \mathrm{~mm}$ ile Soli Pompeipolis'da olduğu Tablo 5'de görülmektedir. Şekil 7'de 1927-2017 yılları arasındaki yağış değerlerinin dağılımları verilmiştir. Buna göre Kilikya Bölgesi'nde ortalama yağışı en fazla alan tarihi yerleşim yerlerinin bulunduğu kısım Dağlık Kilikya Bölgesi'dir. Rakımın yüksek olması yağı̧ı etkileyen parametrelerden biri olsa da [16] rakımı düşük olan Nagidos ve Anemirium yerleşimlerinin etrafında yoğunlaşan ormanlık bölge, buradaki yağışın yoğun olmasında etkili olmuştur.

Tablo 5. 1927-2017 yılları arasındaki ortalama yağış değerleri [15]

\begin{tabular}{lc}
\hline Tarihi Yerleşim Yeri & Ortalama Yağıs Değerleri (mm) \\
\hline Anemurium & 1049 \\
Olba/Uzuncaburc & 618 \\
Nagidos & 913 \\
Celenderis & 709 \\
Corycus & 621 \\
Elaiussa Sebaste & 621 \\
Soli Pompeipolis & 617 \\
Tarsos & 700 \\
Anavarza & 700 \\
Kastabala & 673 \\
\hline
\end{tabular}




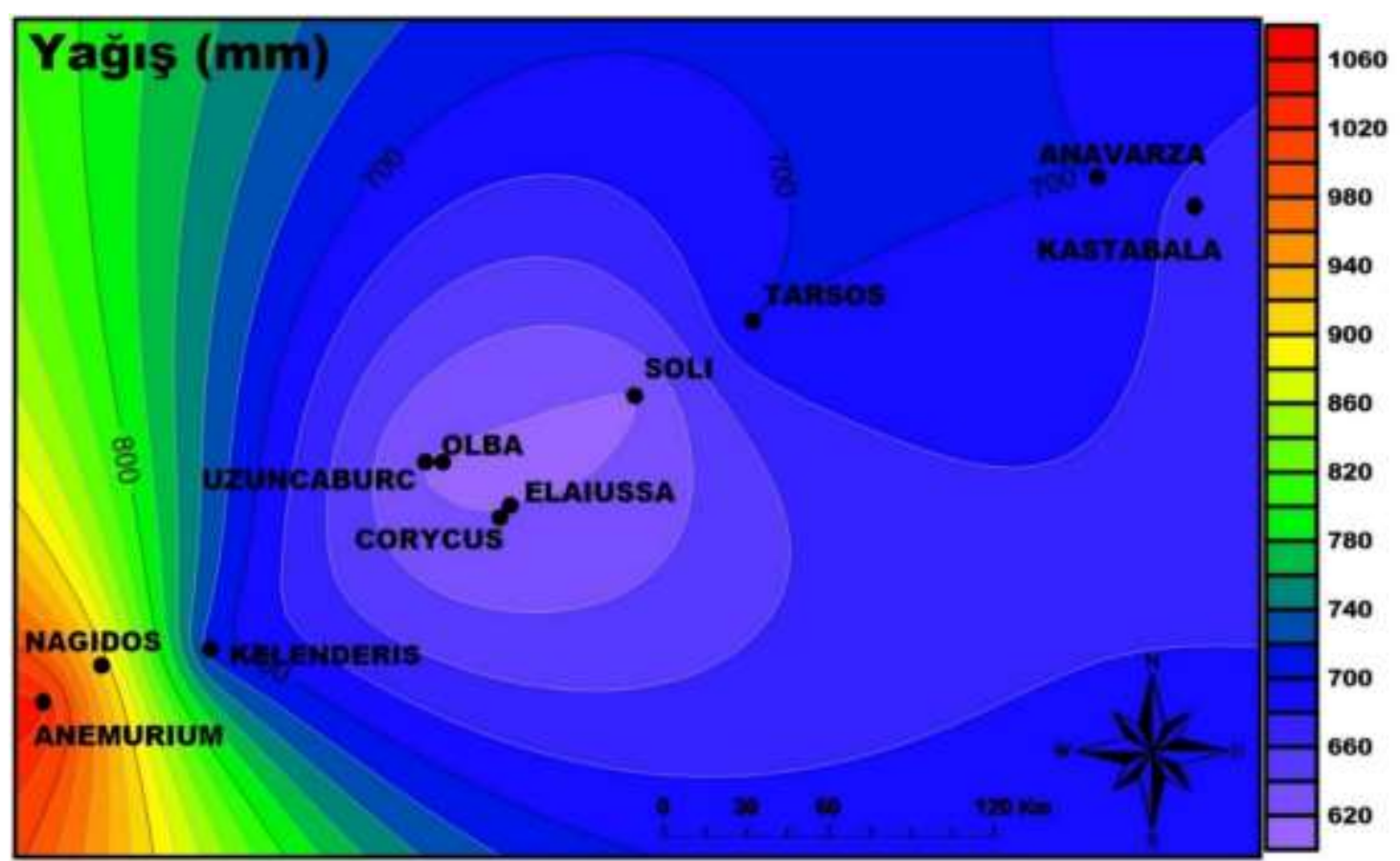

Şekil 7. Çalışma alanının 1927-2017 yılları arasındaki ortalama yağış değerlerinin alansal dağı̆lımı [15]

\subsection{Toprak Türleri}

Çevresel faktörlerden altıncısı toprak türleri parametresidir. Kilikya Bölgesi'nde "Kireçsiz Kahverengi Orman Toprakları", "Kırmızı Akdeniz Toprakları" ve "Alüvyal Topraklar” olmak üzere üç farklı toprak türü bulunmaktadır [17]. Tablo 6'da Kilikya Bölgesi yerleşim yerlerine ait toprak türleri ve Şekil 8'de toprak türlerinin dağılımları görülmekle birlikte alana ait kayaç yapısı bir sonraki başlıkta ayrıca değerlendirilmiştir. Buna göre tarihi yerleşim yeri seçiminde en çok tercih edilen toprak türü "Kırmızı Akdeniz Toprakları" olmuştur. Sonrasında ise sırasıyla "Alüvyal Topraklar" ve "Kireçsiz Kahverengi Orman Toprakları" tercih edilen diğer toprak türleri arasındadır.

Tablo 6. Kilikya Bölgesi yerleşim yerlerine ait toprak türleri [17]

\begin{tabular}{lc}
\hline Tarihi Yerleşim Yeri & Toprak Türleri \\
\hline Anemurium & Kireçsiz Kahverengi Orman Toprakları \\
Olba/Uzuncaburc & Kırmızı Akdeniz Toprakları \\
Nagidos & Kireçsiz Kahverengi Orman Toprakları \\
Celenderis & Kırmızı Akdeniz Toprakları \\
Korycus & Kırmızı Akdeniz Toprakları \\
Elaiussa Sebaste & Kırmızı Akdeniz Toprakları \\
Soli Pompeipolis & Kırmızı Akdeniz Toprakları \\
Tarsos & Alüvyal Topraklar \\
Anavarza & Alüvyal Topraklar \\
Kastabala & Alüvyal Topraklar \\
\hline
\end{tabular}




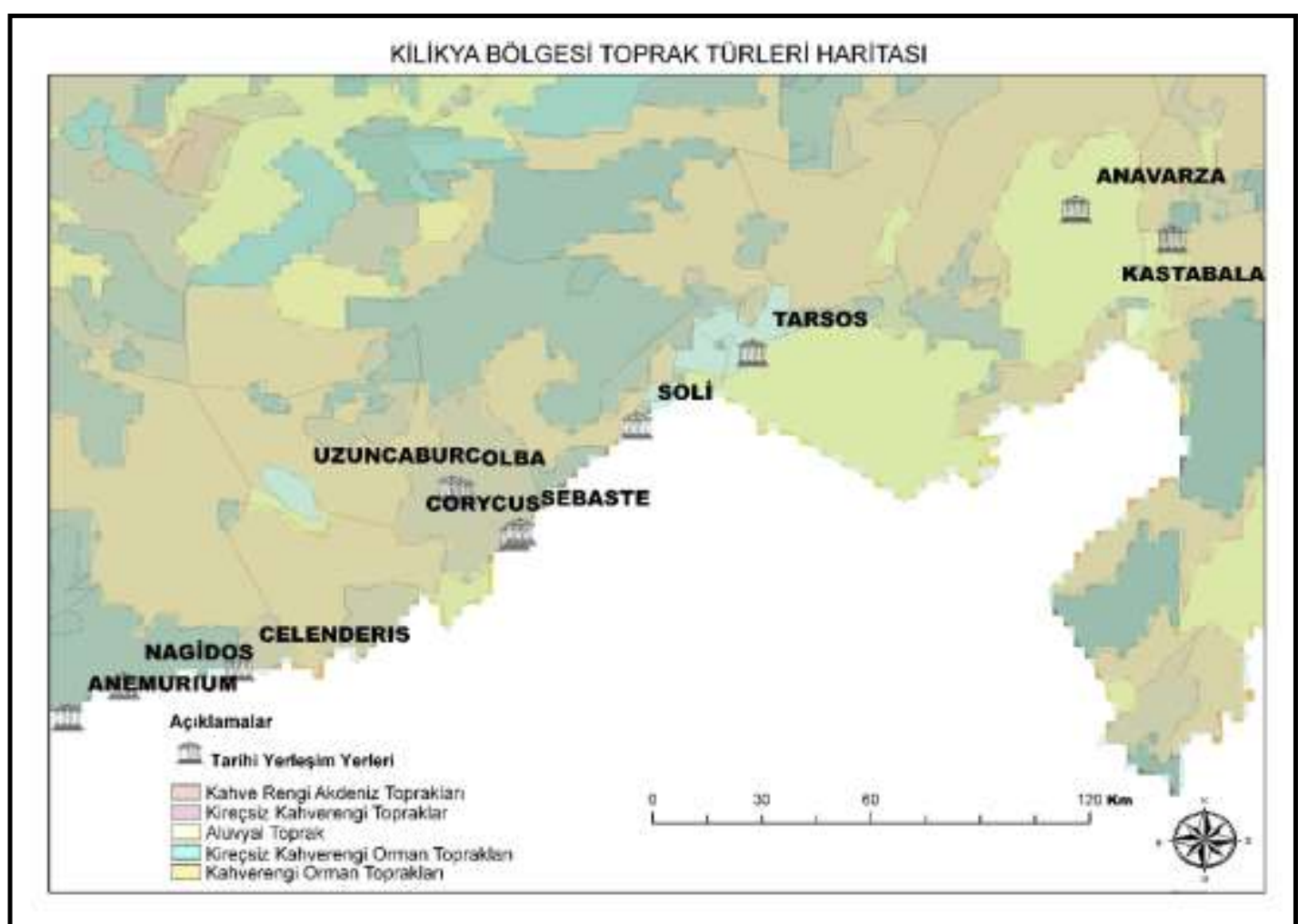

Şekil 8. Kilikya Bölgesi’ne ait toprak türleri haritası [17]

\subsection{Kayaç Yapısı}

Çevresel faktörlerden yedincisi kayaç yapısı (jeolojik formasyon) parametresidir. Kilikya Bölgesi'nde MTA (Maden Tetkik Arama) Genel Müdürlüğü’nden alınan önemli yerleşimlerin kurulduğu kayaç yapısı Tablo 7'de yer almakta olup, yedi farklı kayaç yapısının bulunduğu [13] ve kireç taşı - karbonat içerikli kayaç türlerinin ağırlıkta olduğu görülmektedir. Şekil 9'a bakıldığında Dağlık Kilikya'nın çoğunlukla kireçtaşı kayaç yapısından oluştuğu, Ovalık Kilikya'da ise "kırıntılılar ve karbonatlar" içerikli kayaç yapısının hâkim olduğu söylenebilir.

Tablo 7. Kilikya Bölgesi yerleşim yerlerine ait kayaç yapısı [13]

\begin{tabular}{lc}
\hline Tarihi Yerleşim Yeri & Kayaç Yapıları \\
\hline \multirow{2}{*}{ Anemurium } & Mermer \\
& Sist \\
& Kumul \\
\hline Olba/Uzuncaburc & Kireç taşı \\
\hline \multirow{2}{*}{ Nagidos } & Mermer \\
& Sist \\
& Kumul \\
\hline Kelenderis & Kırıntılar ve karbonatlar \\
\hline Korycus & Kireç taşı \\
\hline Elaiussa Sebaste & Kireç taşı \\
\hline Soli Pompeipolis & Ayrılmamış Kuvaterner \\
\hline Tarsos & Ayrılmamış Kuvaterner \\
& Traverten \\
\hline Anavarza & Kırıntılılar ve karbonatlar \\
\hline Kastabala & Kırıntılılar ve karbonatlar \\
\hline
\end{tabular}




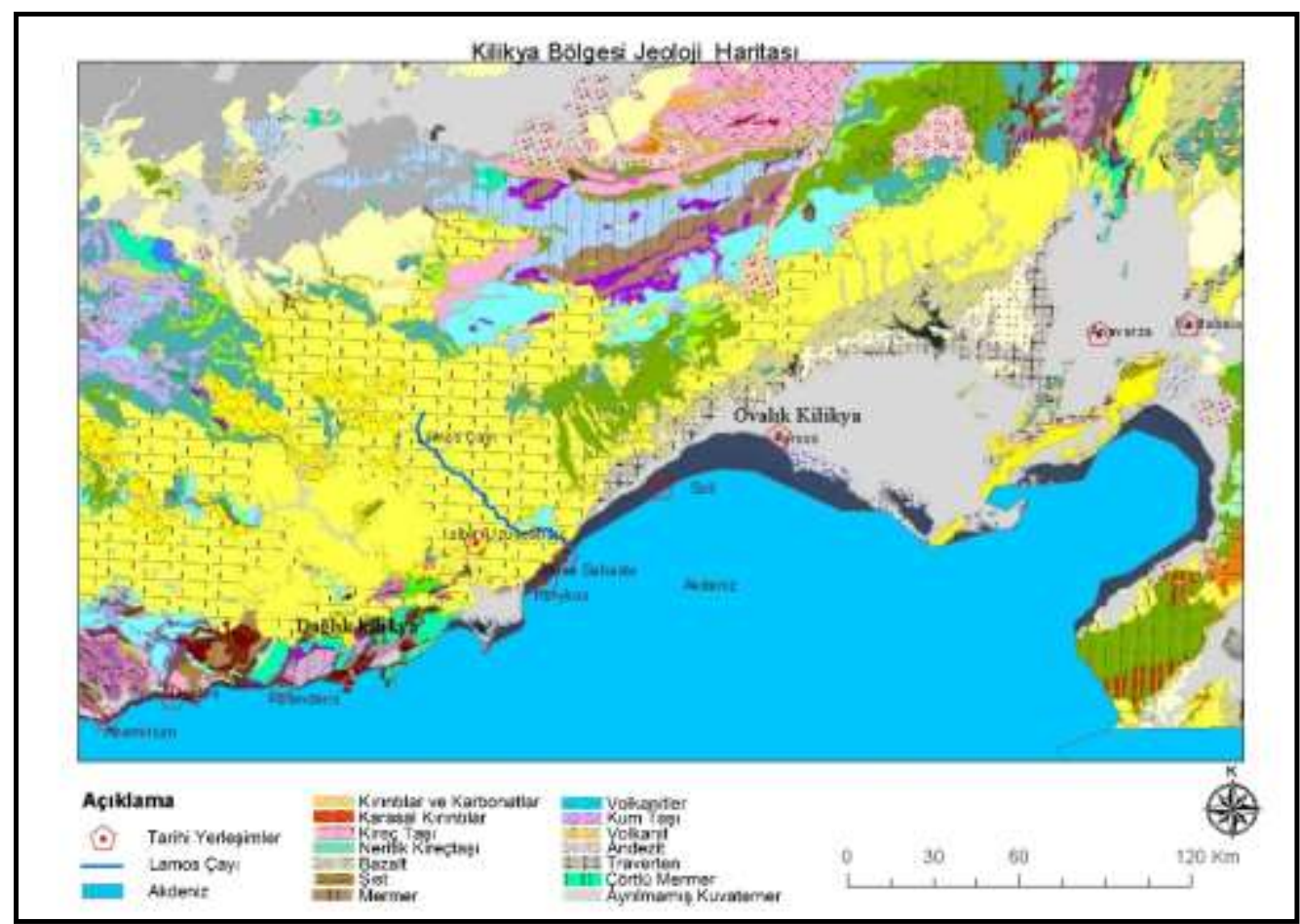

Şekil 9. Kilikya Bölgesi’ne ait kayaç yapısı haritası [13]

\subsection{Su Kaynakları}

Çevresel faktörlerden sekizincisi su kaynakları parametresidir. Çalışma alanının su kaynakları bilgisine Orman ve Su İşleri Bakanlığı'nın Geodata uygulaması üzerinden ulaşılmış olup su kaynakları haritası Şekil 10'da verilmiştir [18]. Su kaynakları haritasına bakıldığı zaman Kilikya Bölgesi küçük akarsu (dere ve çay - sürekli ve geçici akan) bakımından zengin su kaynağına sahip olmasının yanında bölgede; Göksu, Limonlu, Tarsus, Seyhan ve Ceyhan akarsuları gibi büyük su kaynakları da bulunmaktadır. Ayrıca yerleşimlerin tamamının yakınlarında içme suyu ihtiyacını karşılayacak küçük yeraltı suyu kaynaklarının da olduğu görülmektedir. Bu da göstermektedir ki yerleşimlerin birçoğu genellikle su kaynaklarına yakın olan yerlerde kurulmuştur.

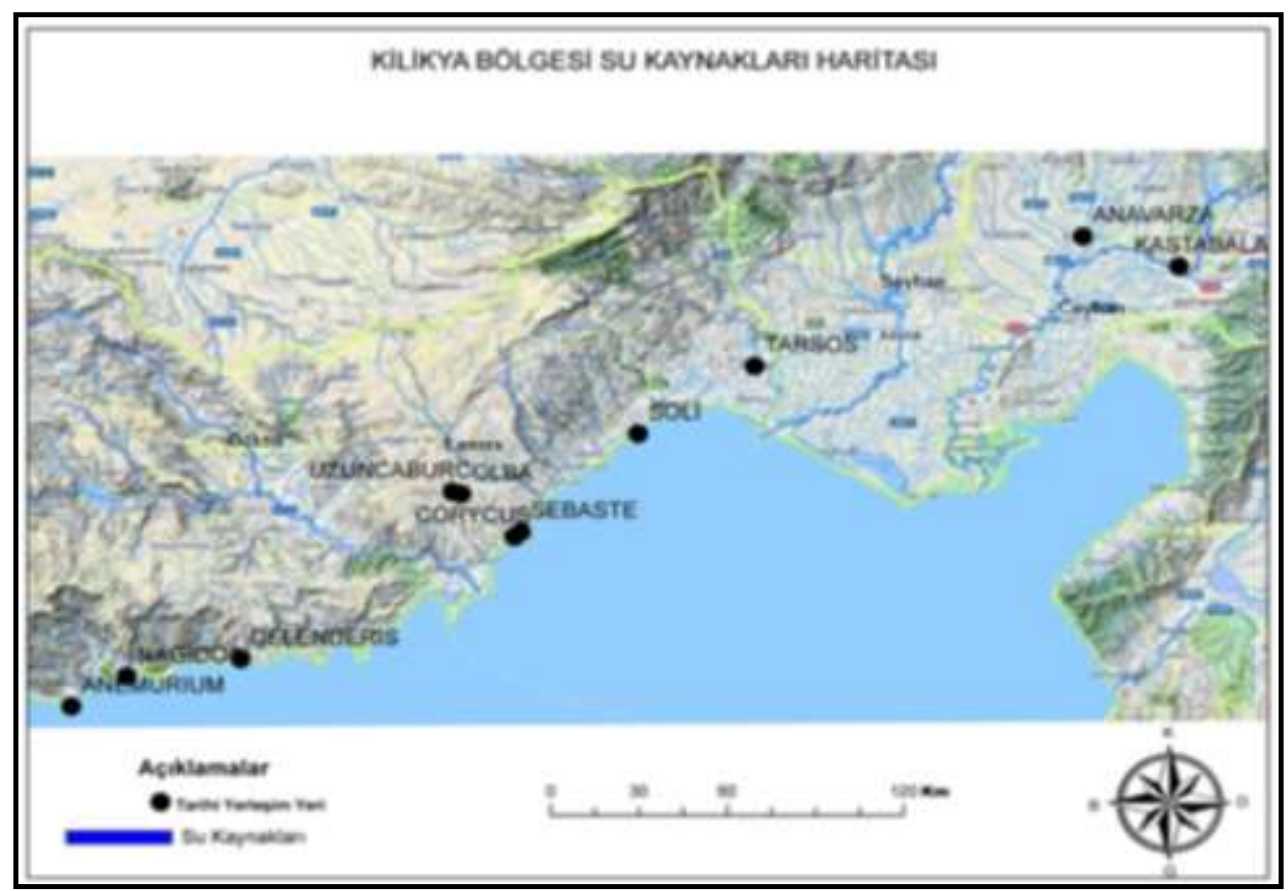

Şekil 10. Kilikya Bölgesi’ne ait su kaynakları haritası [18] 


\subsection{Karayolları}

Çevresel faktörlerden sonuncusu karayolları parametresidir. Kilikya Bölgesi karayolları haritası Şekil 11'de verilmiştir [14]. Buna göre Kilikya Bölgesi; Roma Dönemi ve günümüzde kullanılan yollar karşılaştırıldığında özelikle sahil şeridindeki yollarda büyük benzerliklerle aradan binlerle ifade edilen y1llar geçmesine rağmen güzergâh olarak örtüşmektedir. Özellikle dağlık bölgelerde günümüzde gelişen teknoloji ile tünel ve viyadükler Kilikya Bölgesi karayolu güzergâhlarında farklılıklara neden olmuştur. Ayrıca hem Roma Dönemi'nde hem de günümüzde tüm tarihi yerleşimlere karayoluyla ulaşılabilmektedir. Bu da göstermektedir ki günümüzde olduğu gibi ulaşım kolaylığı yerleşim yerlerinin seçiminde etkili olan parametrelerdendir.

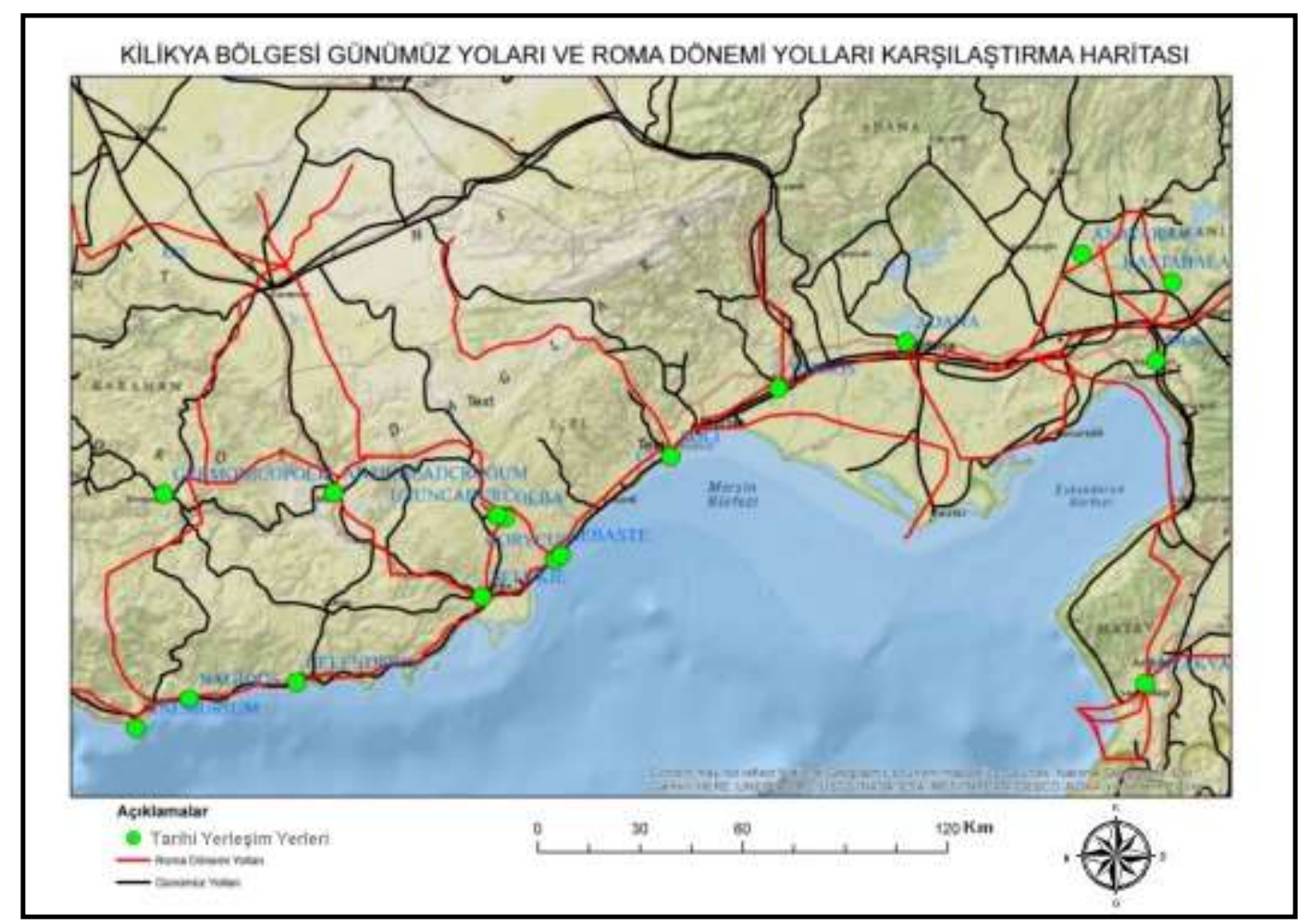

Şekil 11. Kilikya bölgesi Roma Dönemi ve günümüz karayolları haritası [14]

\section{Sonuç ve Öneriler}

Alanya ile İskenderun Körfezi arasında Roma Döneminde Kilikya Bölgesi’nde bulunan Roma Dönemi'ne ait yerleşim yerleri baz alınarak yükselti, bakı, eğim, sıcaklık, yağış, toprak türleri, kayaç yapısı, su kaynakları ve karayolları gibi çevresel faktörlere ait bilgiler CBS'ne aktarılmış ve oluşturulan haritaların analizleri yapılarak bu parametrelerden hangilerinin yaşam alanı seçimi üzerinde etkili olduğu incelenmiştir. Yapılan analizler neticesinde yükselti bakımından $5.5 \mathrm{~m}-1150 \mathrm{~m}$ arasında değerler değişmekte olup en yüksek kesimde kurulan yerleşim Olba / Uzuncaburç ve en düşük kesimde kurulan yerleşim ise Korycus'tur. Bölgenin tamamı dikkate alındığı zaman Dağlık Kilikya'daki yerleşimlerin büyük çoğunluğunun özelikle sahilde ve düşük rakımlı yerlerde yani daha çok düz alanlarda (\%10 eğimin altında) olduğu tespit edilmiştir. Bakı yönleri bakımından yerleşimlerin yönleri farklılıklar göstermekle birlikte en çok tercih edilen kuzeybatı ve güneydoğu yönleri olmuştur. Kuzey yönü ise hiç tercih edilmemiştir. 1927-2017 yılları arasındaki ortalama sıcaklık değerlerinin 18.5 üzerinde olmakla birlikte ve tüm yerleşimlere ait sıcaklıkların genellikle birbirine çok yakın değerlerde olduğu ifade edilebilir. 1927-2017 yılları arasındaki ortalama yağış değerleri 617 mm (Soli Pompeipolis) - 1049 mm (Anemurium) arasında olup, ortalama yağışı en fazla alan tarihi yerleşim yerlerinin bulunduğu kısım Dağlık Kilikya Bölgesi'dir. Rakımın yüksek olması yağışı etkileyen parametrelerden biri olmasına rağmen rakımı düşük olan Nagidos ve Anemurium yerleşimlerinin etrafında yoğunlaşan ormanlık bölge, buralarda da yağışın fazla görülmesini etkilemiştir. Buna göre tarihi yerleşim yeri seçiminde toprak türü olarak "Kırmızı Akdeniz Toprakları", "Alüvyal Topraklar" ve "Kireçsiz Kahverengi Orman Toprakları" 
arasında en çok tercih edilen "Kırmızı Akdeniz Toprakları" olmuştur. Kayaç yapısına bakıldığı zaman yedi farklı kayaç yapısından kireç taşı-karbonat içerikli kayaç türlerinin ağırlıkta olduğu; Dağlık Kilikya'nın çoğunlukla "kireçtaşı" kayaç yapısından oluştuğu ve Ovalık Kilikya' da ise "kırıntılılarkarbonatlar" içerikli kayaç yapısının hâkim olduğu söylenebilir. Su kaynakları bakımından Göksu, Limonlu, Seyhan ve Ceyhan akarsuları gibi büyük su kaynakları çalışma sınırında bulunmakla birlikte yerleşimlerin tamamının genellikle büyük ve küçük su kaynaklarının yakınlarında kurulduğu görülmektedir. Eski dönem ve günümüzde kullanılan karayolları karşılaştırıldığında özelikle sahil şeridindeki yollarda büyük benzerliklerle güzergâhlar örtüşmektedir Dağlık bölgelerde günümüzde gelişen teknoloji ile tünel ve viyadükler karayolu güzergâhlarında farklılıklar meydana getirmiştir. Dikkate alınan çevresel faktörler ışığında henüz ortaya çıkmamış eserlerin yerlerinin tespiti aşamasında bu çalışmanın sonraki çalışmalara ışık tutacağı düşünülmektedir.

\section{Yazarların Katkısı}

Çalışmaya tüm yazarlar eşit oranda katkı sunmuştur.

\section{Çıkar Çatışması Beyanı}

Yazarlar arasında herhangi bir çıkar çatışması bulunmamaktadır.

\section{Araştırma ve Yayın Etiği Beyanı}

Yapılan çalışmada araştırma ve yayın etiğine uyulmuştur.

\section{Kaynaklar}

[1] Yılmaz A., Yaman H. 2012. Toplum Güvenliğinde Bir Örgütlenme Modeli: Dünya Sağlık Örgütü Güvenli Toplumlar Ağı. Polis Mesleki Fikir, Hizmetiçi Haberleşme ve Kültür Dergisi, 70: 93103.

[2] Durugönül S. 2007. Dağlık Kilikia'da bir antik kent kazısının sonuçları Nagidos. Suna-İnan Kıraç Akdeniz Medeniyetleri Araştırma Enstitüsü, İstanbul.

[3] Bank E. 1990. Coğrafi Veri Tabanı Tasarımı. Yüksek Lisans Tezi, Yıldız Teknik Üniversitesi, Fen Bilimleri Enstitüsü, İstanbul.

[4] Demir Yetiş A. 2009. Akyatan Lagünü'nde tuzluluk ve bazı kirlilik düzeylerinin saptanarak Coğrafi Bilgi Sistemi destekli dağılımlarının belirlenmesi. ÇÜ Fen Bilimleri Enstitüsü Dergisi, 20 (1): 187-199.

[5] Çakır M.E., Demir Yetiş A., Yeşilnacar M.İ., Ulukavak M. 2019. Katı Atıklar için Optimum Güzergâh Tespiti ve Alansal Dağılım Haritalarının CBS Ortamında Oluşturulması: Suruç (Şanlıurfa) Örneği. BEU Fen Bilimleri Dergisi, 8 (2): 595-603.

[6] Kardeş H. 2010. Kahta bölgesinin arkeolojik öneme sahip alan ve eserlerinin CBS yardımıyla veri tabanının oluşturulması ve mevcut kullanımının belirlenmesi. Yüksek Lisans Tezi, Çukurova Üniversitesi, Fen Bilimleri Enstitüsü, Adana.

[7] Pişkin G. 2011. Aliağa ve çevresindeki Arkeolojik Yerleşimlerin CBS ile Mekansal Analizi. Yüksek Lisans Tezi, Ege Üniversitesi, Sosyal Bilimler Enstitüsü, İzmir.

[8] Durugönül S. 2002. Development of Ancient Settlements in Cilicia. Adalya, 5 (2001-2002): 107119.

[9] Strabon. 2000. Geography, Bohn's Classical Library, London 1854 (Eserin Anadolu ile ilgili kısmının çevirisi: Antik Anadolu Coğrafyası (Geographika: XII-XIII-XIV), Çev. Adnan Pekman, Arkeoloji ve Sanat Yayınları, İstanbul.

[10] Tahberer B. 2005. Antik Kilikya Sikkelerinde Asklepios Kültü. Yüksek Lisans Tezi, Çukurova Üniversitesi, Sağlık Bilimleri Enstitüsü, Adana.

[11] Kaya İ. 2019. Kilikya Roma Dönemi Kentleri ve Nekropollerinin Coğrafi Bilgi Sistemleri Destekli Mekânsal ve Sosyal Analizi. Yüksek Lisans Tezi, Bitlis Eren Üniversitesi, Fen Bilimleri Enstitüsü, Bitlis. 
[12] USGS (U.S. Geological Survey). 2018. https://earthexplorer.usgs.gov/ (Erişim Tarihi: 15.01.2018).

[13] MTA (Maden Tetkik Arama Genel Müdürlüğ̈̈). 2018. http://yerbilimleri.mta.gov.tr/anasayfa.asp (Erişim Tarihi: 25.02.2018).

[14] Anonim. 2018. http://www.pelagios.orgmapsgreco-roman (Erişim Tarihi: 28.02.2018).

[15] MGM (Meteoroloji Genel Müdürlügü). 2018. https://www.mgm.gov.tr/veridegerlendirme (Erişim Tarihi: 17.12.2018).

[16] Sarı S. 2016. Anamur (Mersin) İlçesinde sıcaklık ve yağış dağılışını etkileyen faktörler. Marmara Coğrafya Dergisi, 34:178-194.

[17] Anonim. 2018. https://www.ahmetkrgn.com/, CBS ve Haritacılık, (Erişim Tarihi: 26.02.2018).

[18] TOBGEODATA (Tarım ve Orman Bakanlığ1, Geodata). 2018. http://geodata.ormansu.gov.tr/ (Erişim Tarihi: 24.02.2018). 